\title{
高純度アルミニウムマグネシウム合金の研究(第 1 報)
}

\section{Reflectal 合金に就て}

STUDY ON THE Al-Mg ALLOYS BASED ON HIGHT-PURITY ALUMINUM (Part 1)

On the "Reflectal" Alloy

\begin{tabular}{|c|c|c|}
\hline $\begin{array}{l}\text { 川 } \\
\text { NAMIO }\end{array}$ & & $\begin{array}{c}\text { 泿 夫 } \\
\text { KAWASHIMA }\end{array}$ \\
\hline 中 & 村 & 雄造 \\
\hline
\end{tabular}

Recently, the Al-Mg alloy based on high-purity aluminum are used for reflectors, utensils, fittings, dentistry and jewellery in abroad.

Electrolytically polished and anodized high-purity aluminum (99.99\% up) has excellent reflection properties, but its strength is too low to use for them. It is said that an addition of $0.3-1.0 \% \mathrm{Mg}$ improves its strength without deteriorating the reflection properties and corrosion resistance.

These alloys are called as Reflectal, Lurium and etc.

In this parer the properties of Raffinal, Reflectal 0.5 , Reflectal 1.0 and other alloys are compared with those of $99.7 \% \mathrm{Al}$ to ascertain the effect of $\mathrm{Mg}$ addition.

金属定䨘解研磨したものは各波長の光に対し特有の反 射能を有するわけであるが、各種の金属に対し Fig.1 に示す様な傾向が知られている(1)。即ち可視線部の波 長の範团(0.4 0. $8 \mu$ に於ては反射 率は $\mathrm{Ag}$ が最高で $\mathrm{Al}$ が之についで いるが、紫外線部 に於ては $\mathrm{Ag} よ り$ あ $\mathrm{Al}$ の方が著し く高い。

己に高純度アル ミ板について電解 研碳すると素晴し い反射能を有し之 に軽い陽極酸化を 行い各種の反射鏡 として使用されて 居り、その寿命も 相当長く保証され ている。然し乍ら 29.99\%Al では何 分にも極軟筫であ り、且結品粒が粗 大で絞り加工に適
せず従つてその利用面に於て制約を受けざるを得ない。 この点を改善したものが Reflectal でその成分は 99.99\% $\mathrm{Al}$ に $\mathrm{Mg}$ を 0.3〜2\%の範囲で涯加したものである。

Fig I Variations of Reflectivities of Various Metals against Wave Length.

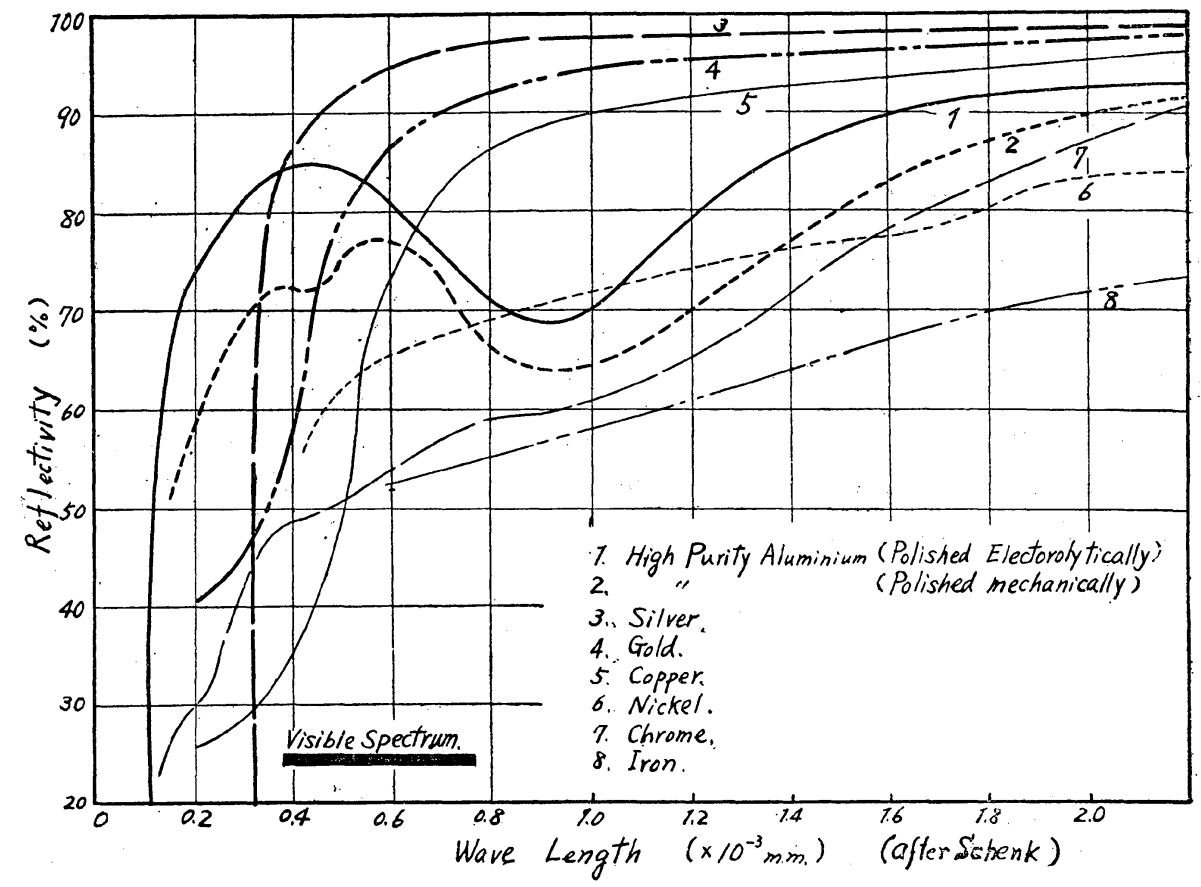

* 東洋アルミニウム株式会社取締役工場長工学搏士 Toyo Aluminium K. K. 
又この種の合金が Brillalumag，Lurium 等の名称で欧 米では最近盛んに反射鏡、装身具、齿科用等に使用され ており、高純度アルミ欧びその合金の反射镜に関する研 究も最近多数発表されている。2)-11)

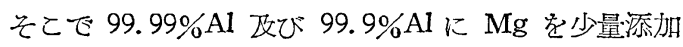
乙た合金について機械的性質、耐蝕性等について㭘討を 試みた。

Table 1 Chemical Compositions of Specimen

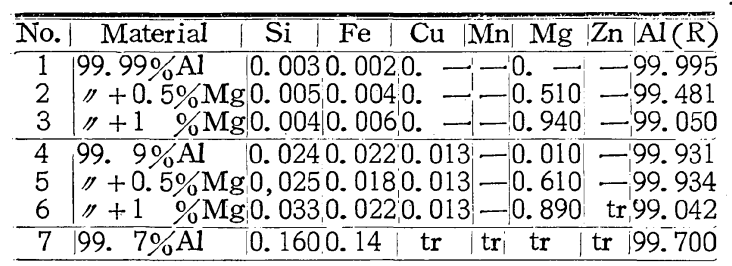

\section{試料及び試験方法}

純度 $99.99 \%$ の高純度アルミに Mg 0.5\%及び 1.0\% 涯加して $1 \mathrm{~kg}$ Slabに Cast した。その鋳造条件は湯温 約 $800^{\circ} \mathrm{C}$ 鋳込温度約 $760^{\circ} \mathrm{C}$ 鋳型温度 $280 \sim 300^{\circ} \mathrm{C}$ であ る。合 99.9\% $\mathrm{AI}$ 及び $\mathrm{Mg} 0.5$ 及び 1.0\%加えたもの 99.7\% Al も之之同椂な条件て Slab を作つた。これら の成分は Table 1 に示す通りである。

これらの Slabを次の如く压延した。

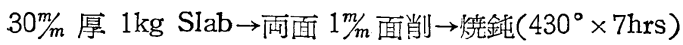

$\rightarrow$ Cold Roll. $6 \frac{m}{m} \rightarrow$ 軟化 $\left(420^{\circ}\right.$ $\times 8 \mathrm{hrs}) \rightarrow$ Cold Roll $0.4 \mathrm{~m} / \mathrm{m}$

之等の試料を压延の儘、各温 度に $1 \mathrm{hr}$ 電気师にて軟化空冷乙 て硬度を測定し（微小硬度計50 $\mathrm{g} w \mathrm{t})$ 軟化曲線学求女先つ”再絓 晶温度を検討した。更に抗張力 伸を測定し (500kgs Shopper type の引(張試験機) 軟化曲線を 求めた。

叉ェリクゼン試験も行つてそ の值と肌荒状況を観察した。更 に各軟化材のミクロ組織につい て検討した。

反射能については Fig. 2 に 示す様な測定装置を使用した。

即ち Stabilizer として比色計 用のものを利用し、その光源上 りの光を、始女直線的に Photo Cell に受けて lux meter を読 夕更に図の様に lux meter とを $90^{\circ}$ 方向に迴して試料面に $45^{\circ}$ の方向から光束を投射し之を受
けたときの Iux meter の読及を取りそ朼を求めて反 射率とした。

試料は $\mathrm{Cr}_{2} \mathrm{O}_{3}$ 粉觉添加した約 $3 \% \mathrm{H}_{3} \mathrm{PO}_{4}$ にて酸化

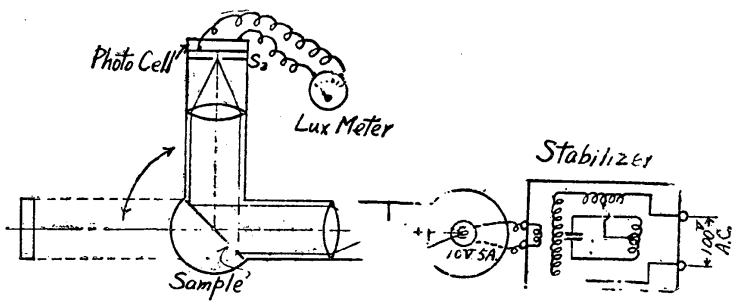

Fig. 2 Apparatus for Mesurement of Reflectivity 皮膜索除去し次いで無水醮酸、過塩索酸 $(78: 22)$ 中に て D.C. $5 \mathrm{~A} / \mathrm{dm}^{2}$ にて10分閒電解研磨を行つた。又は之 に陽極酸化 $\left(\mathrm{H}_{2} \mathrm{SO}_{4} 5 \%\right.$ D.C. $\left.10 \mathrm{~V}\right)$ を行つた。同之等 の耐蝕性については $\mathrm{HCl}, \mathrm{NaOH}$ 中にての麻蝕減量を測 定した。

\section{試驗結果}

\section{1）再結晶溫度}

硬度曲線はFig. 3,4 に示す如くである。之から再結 晶完了温度で求めると次の通りである。
$99.995 \% \mathrm{Al}+0.5 \% \mathrm{Mg}+1 \% \mathrm{Mg}$ $300^{\circ}$ $320^{\circ}$ $320^{\circ}$
99. $9 \% \mathrm{Al}+0.5 \mathrm{Mg}+1 \% \mathrm{M}$ $320^{\circ} \quad 340^{\circ} \quad 340^{\circ}$
99.7 $280^{\circ}$

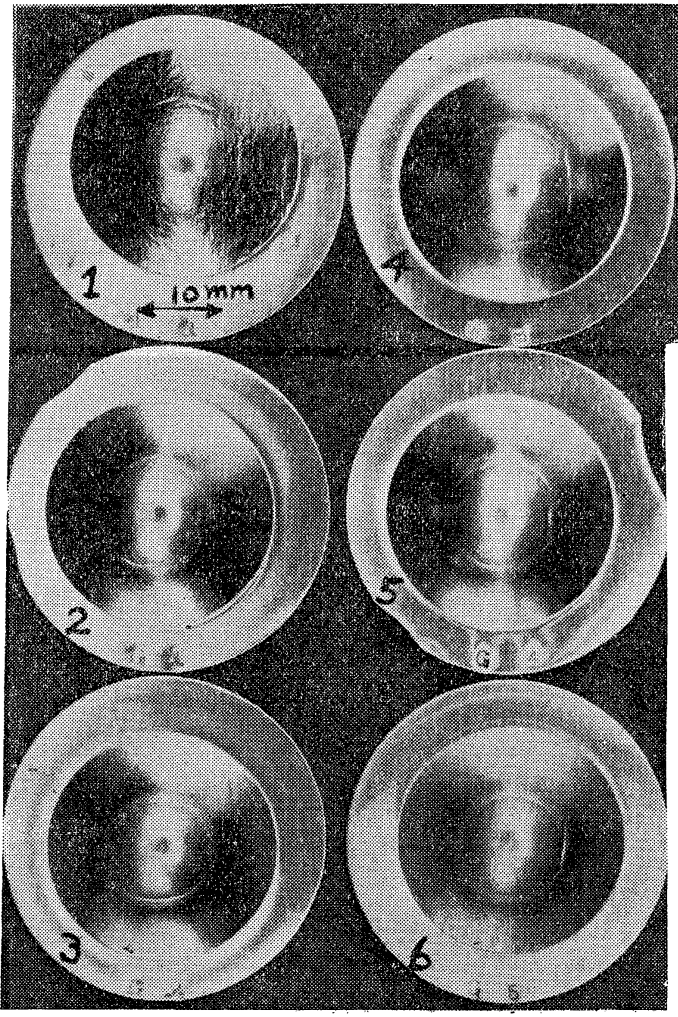

Photo. 1 Result of Erichsen Test

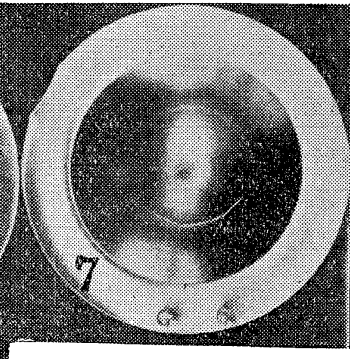

$\mathrm{Mg}$ 添加による再結晶 温度への影響については 著者等12) の前の結果と 同様に之を上昇させる傾 向がある。

2）機械的性啠

抗㲀力、伸についての 軟化曲線は Fig. 5〜8 に 示す通りである。又参考 迄に交献 ${ }^{8)}$ に上る Raffinal, Reflectal の機械的 性質を Table 2 に示し て置いた。

硬度機械的性筫につい ては 99.99\% Al に Mg 
Fig 3 Annealing Lerves of $99.99 \%$ Aluminium Reflectal Alloys

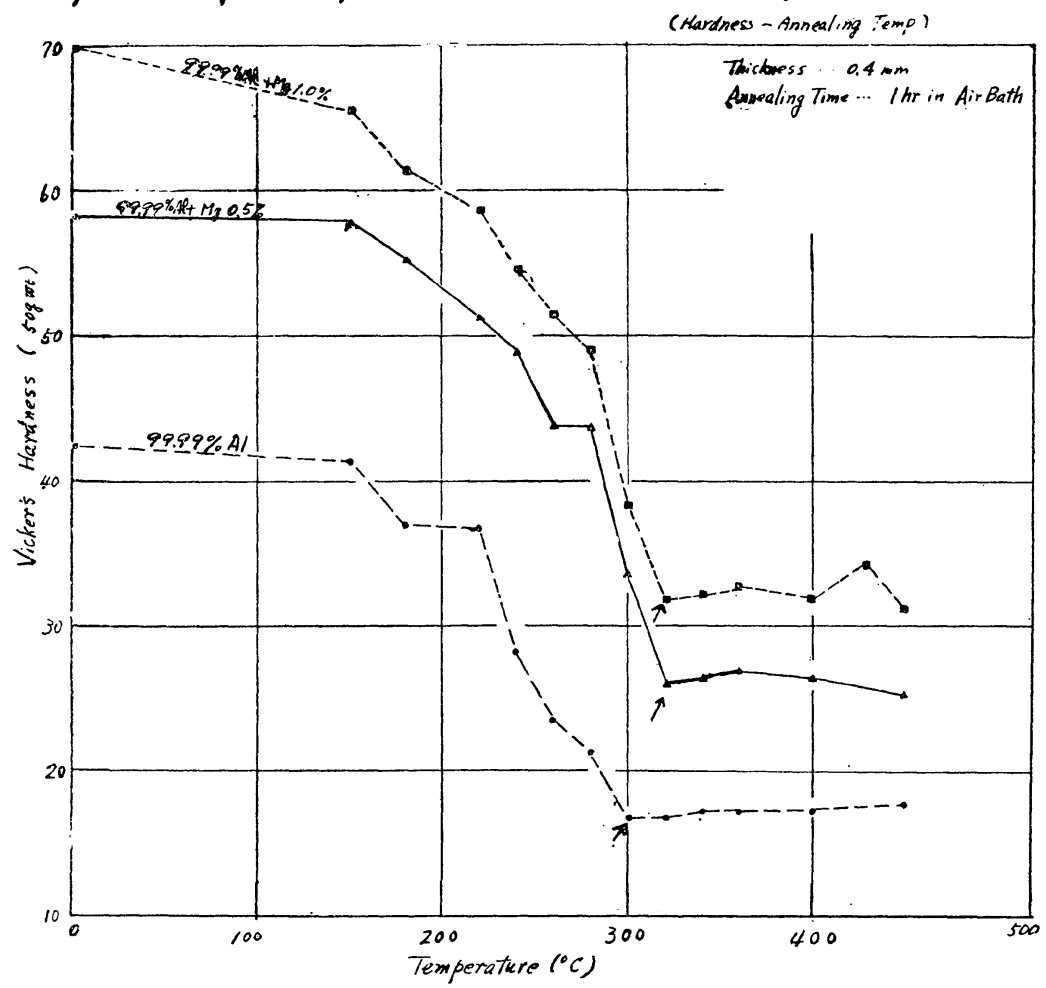

Fig. 4 Ampealing Curves of 99.9\% Aluminum, Its Alloys Added Magnesium and $99.7 \%$ Alumimum.

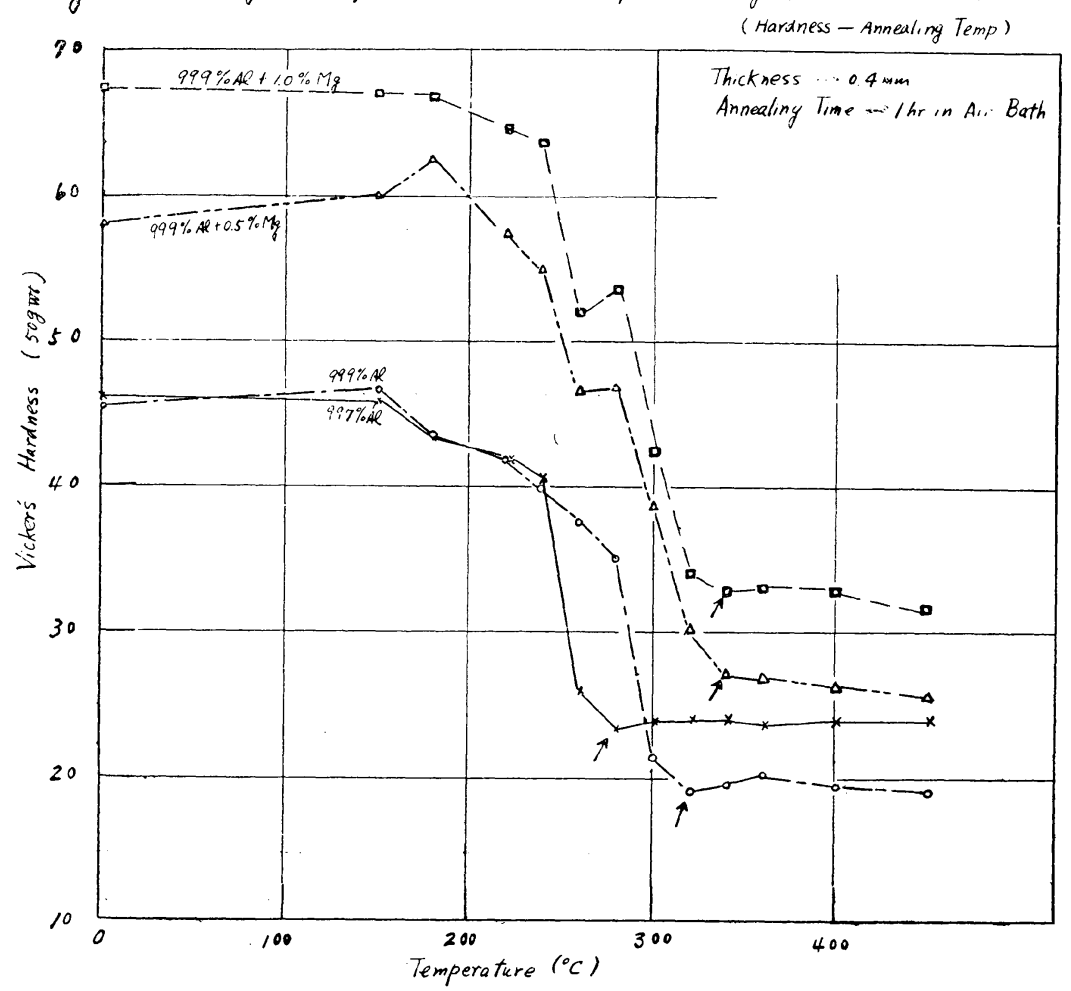


Fig. 5 Annealing Curres - of $99.99 \%$ Aluminium and Reflectal Alloys.

(Tensile Strength-Annuding Temp)

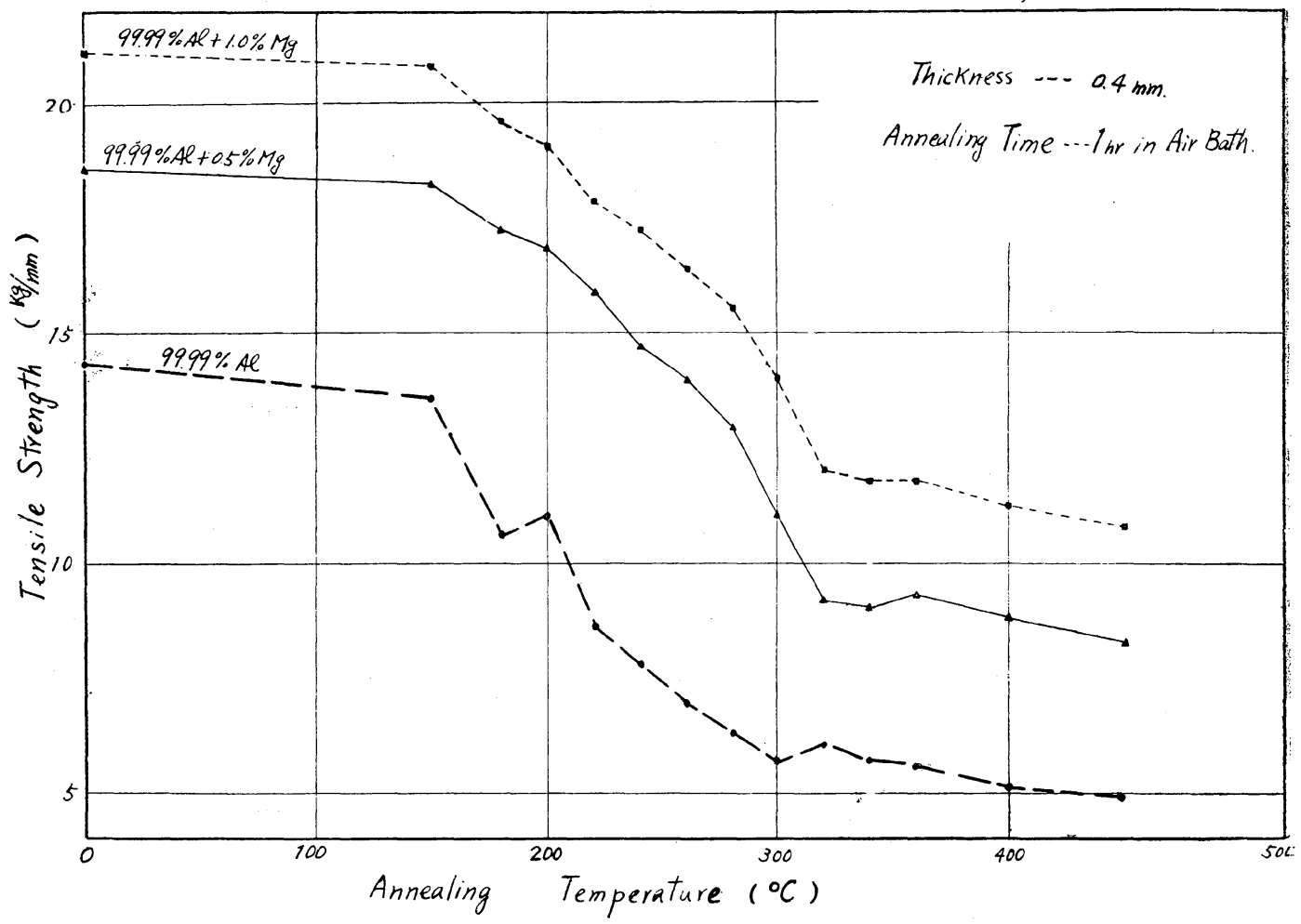

Fig. 6 Annealing Curves of 999\% Aluminium, Its Alloys Added Magnesium and $997 \%$ Aluminium. (Tensile Strength - Annealing Temp.)

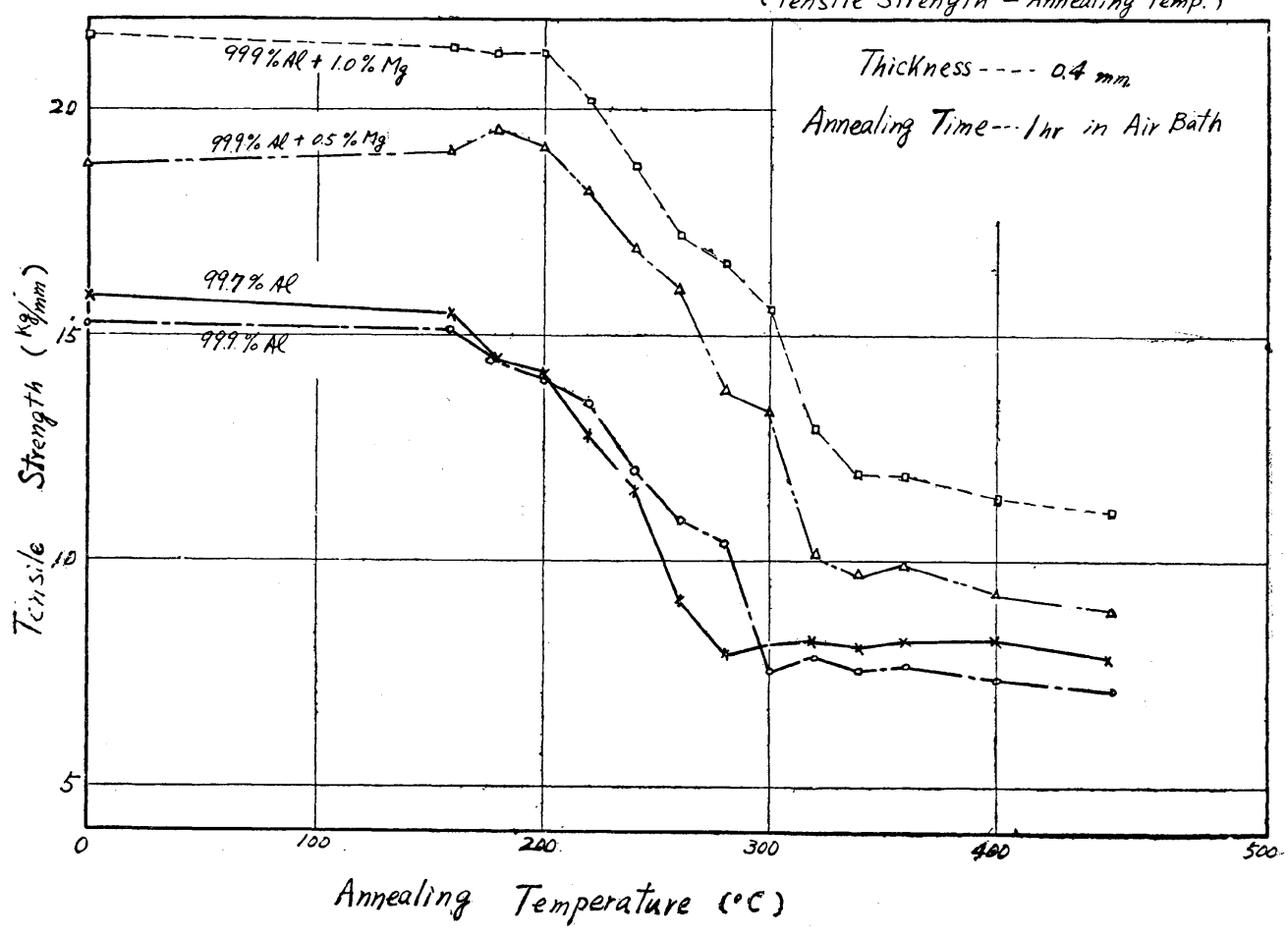


Fig. 7 Annealing Curves of $99.99 \%$ Aluminium and Reflectal Alloys.

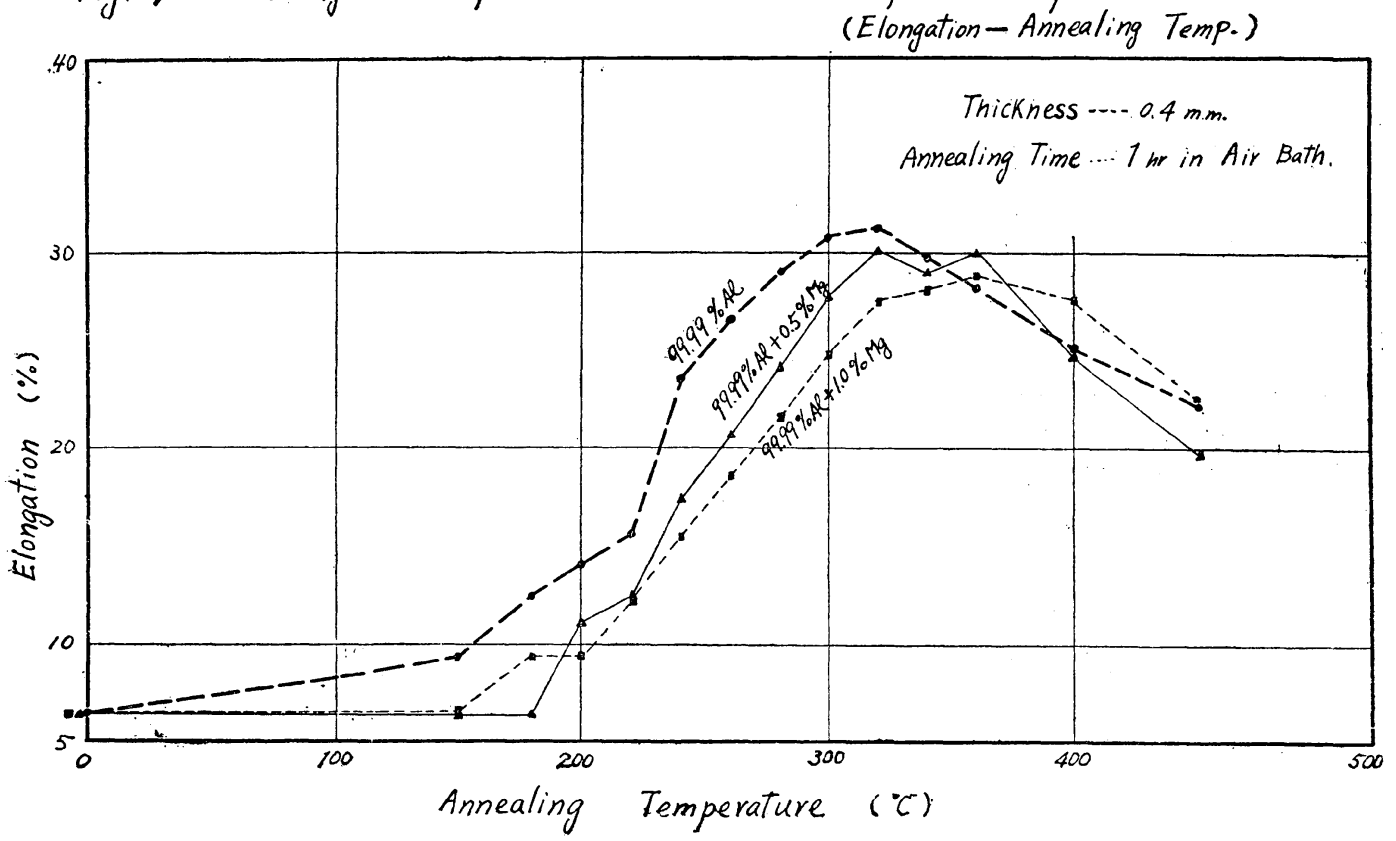

Fig. 8 Annealing Curves of $99.9 \%$ Aluminium, Its Alloys Added Magnesium and $99.5 \%$ Aluminium.

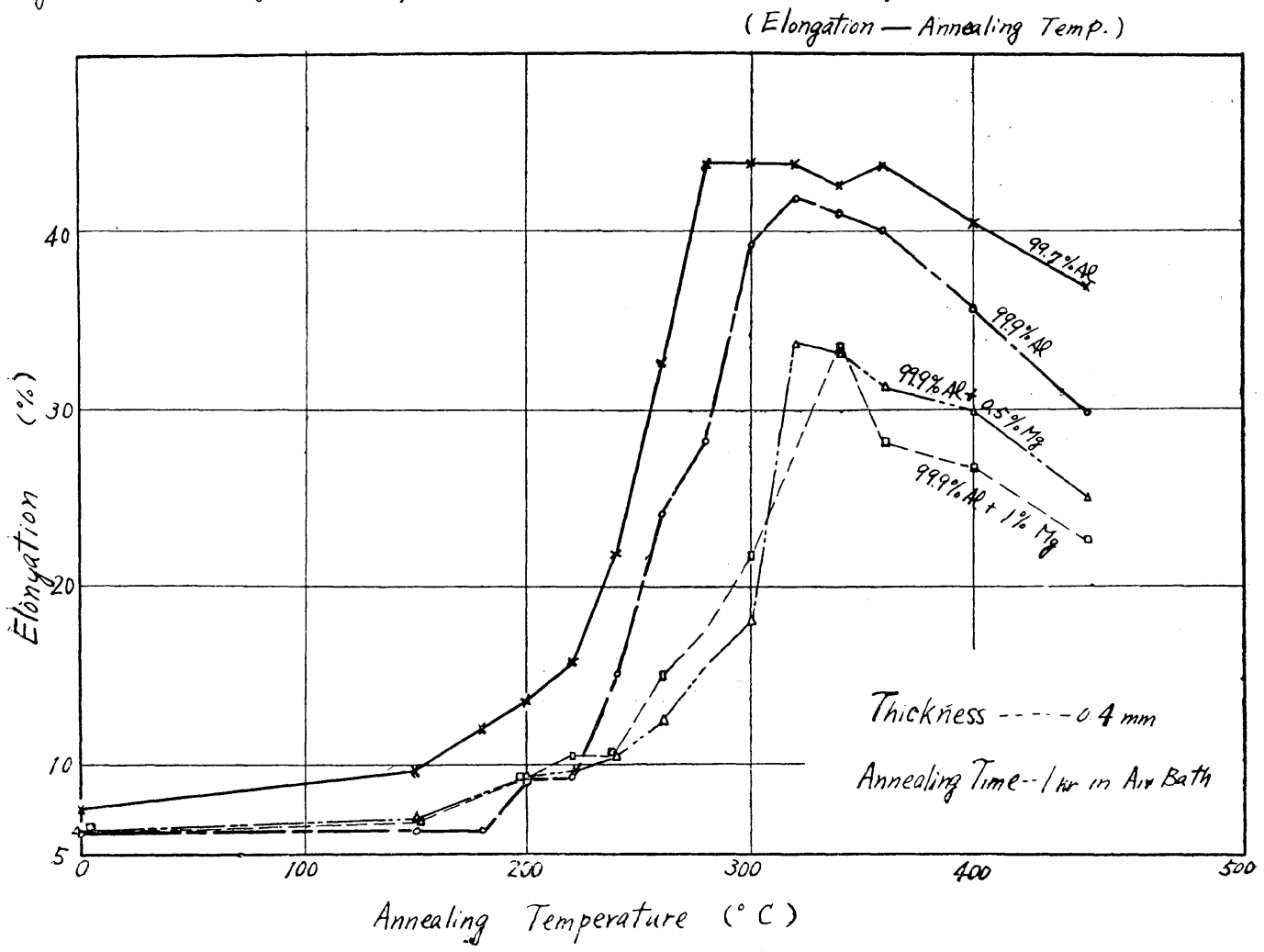


添加により予想通り向上し $0.5 \%$ ては $2 \mathrm{~S}, 1 \%$ $3 \mathrm{~S}$ の硬度のも のが得られる。

エリクゼン值はFig.9に示す如 く H林、O材共に概して $\mathrm{Mg}$ 添 加により低下する。但し $99.99 \%$ Al O材以著しい肌荒れ (Orange peel)を生じている。

そに対して $\mathrm{Mg}$ を涯加したもの は 0.5\%で Orange peel は消元て いるし(Photo. 1参照) 2S 程度の 抗張性となるので絞り加工性は著 しく改善されることが判る。

\section{3）顯德鏡組織}

軟犋材 $\left(350^{\circ} \times 1 \mathrm{hr}\right.$ 加熱空冷)の 各試料に於て $99.99 \% \mathrm{Al}$ はかな り結晶粒は大きい $(\phi 0.138 \mathrm{~m} / \mathrm{m})$ が $0.5 \% \mathrm{Mg}$ の添加で相当細か $(\phi$ $0.49 \mathrm{~m} / \mathrm{m}$ )になり $1 \%$ て更に幾分細 加（０.046）になつている。

然し 99.9\% ( $\left.\phi 0.053 \frac{m}{m}\right)$ では Mg 0.5\%、1\%㬄加で僅かに細か （夫љ $\phi 0.046,0.038 \mathrm{~m} / \mathrm{m}$ ) になる 程度である。

即占 $99.99 \% \mathrm{Al}$ に $0.5 \% \mathrm{Mg}$ を涯加すれば $99.9 \% \mathrm{Al}$ の結晶粒 よりも稍々小さくなつているので 絞り加工性も改良される事が突は れる。

\section{4) 反射率}

測定結果它 Fig. 10 に示す。 平均曲線苍是ると電解研磨の嫿 では硬質 99.99\% Al は98\%に反
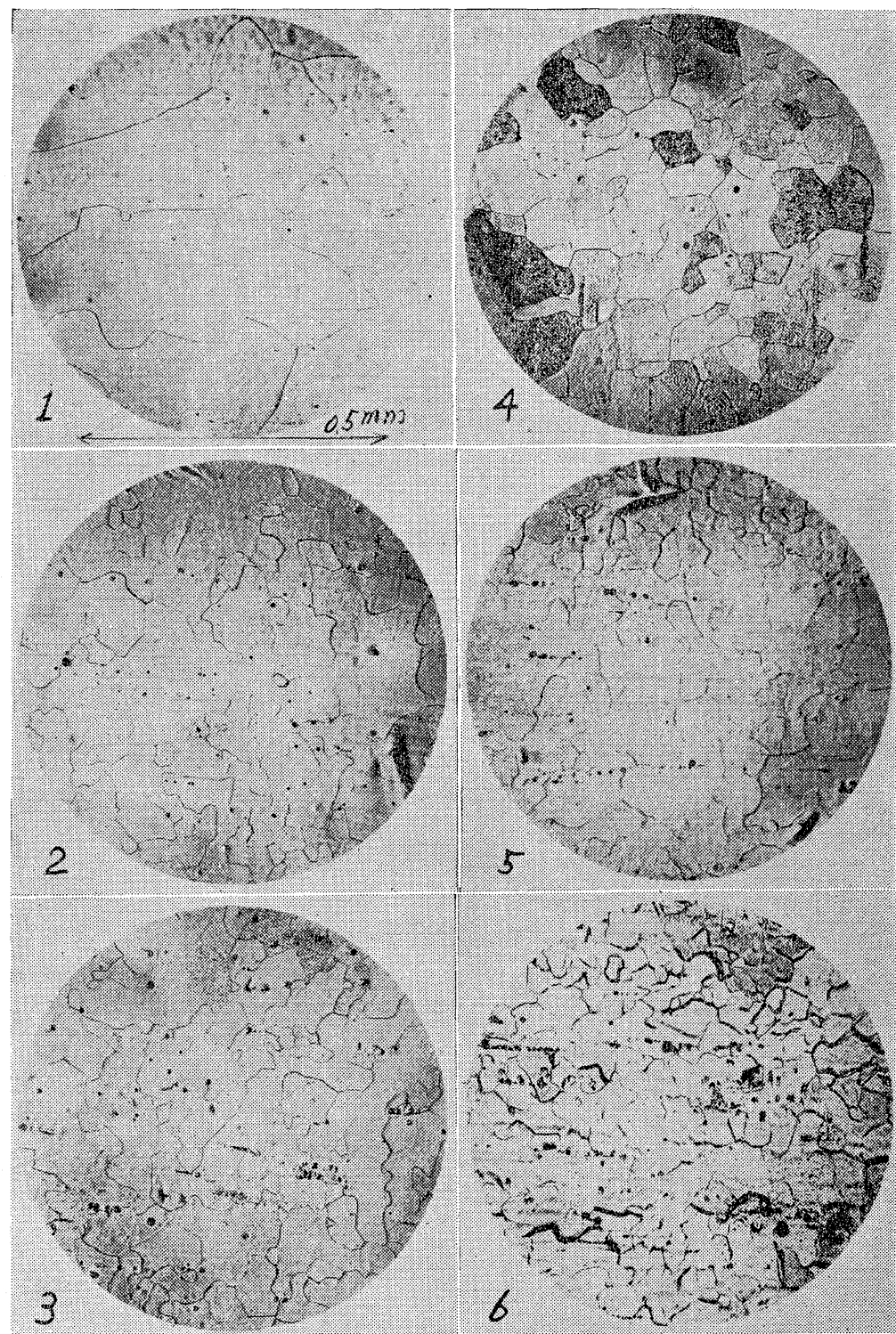

Table 2 Mechanical Properties of 99.99\% AI, 99.5\% AI and "Reflectal"

\begin{tabular}{l|c|c|c|c}
\hline \hline Material & Condition & $\begin{array}{c}\text { Tensile } \\
\text { Strength } \\
\mathrm{kg} / \mathrm{mm}^{2}\end{array}$ & $\begin{array}{r}\text { Elongn } \\
\%\end{array}$ & $\begin{array}{c}\mathrm{B} . \mathrm{H} . \mathrm{N} . \\
\mathrm{kg} / \mathrm{mm}^{2}\end{array}$ \\
\hline \multirow{2}{*}{$99.99 \% \mathrm{Al}$} & $\mathrm{O}$ & 6.2 & 43.0 & $16 \sim 19$ \\
& $\mathrm{~T} / \mathrm{H}$ & 7.7 & 19.7 & $20 \sim 24$ \\
& $\mathrm{H}$ & 11.9 & 7.2 & $28 \sim 32$ \\
\hline $99.99 \% \mathrm{Al}+0.5 \% \mathrm{Mg}$ & $\mathrm{O}$ & 8.8 & 29.9 & $25 \sim 28$ \\
(Reflectal 0.5) & $\mathrm{I} / \mathrm{H}$ & 11.6 & 7.8 & $34 \sim 36$ \\
& $\mathrm{H}$ & 14.7 & 5.7 & $40 \sim 42$ \\
\hline 99.99\% Al+2.3\% Mg & $\mathrm{O}$ & 18.4 & 30.0 & $41 \sim 44$ \\
(Reflectal 2) & $\mathrm{T} / 2 \mathrm{H}$ & 26.0 & 4.6 & $68 \sim 72$ \\
& $\mathrm{H}$ & 33.5 & 3.5 & $84 \sim 86$ \\
\hline & $\mathrm{O}$ & 8.0 & 30.0 & $18 \sim 23$ \\
$99.5 \% \mathrm{Al}$ & $\mathrm{T} / 2 \mathrm{H}$ & 10.0 & 12.0 & $26 \sim 30$ \\
& $\mathrm{H}$ & 15.5 & 6.5 & $35 \sim 40$ \\
\hline
\end{tabular}

(after Helling and Henzig)

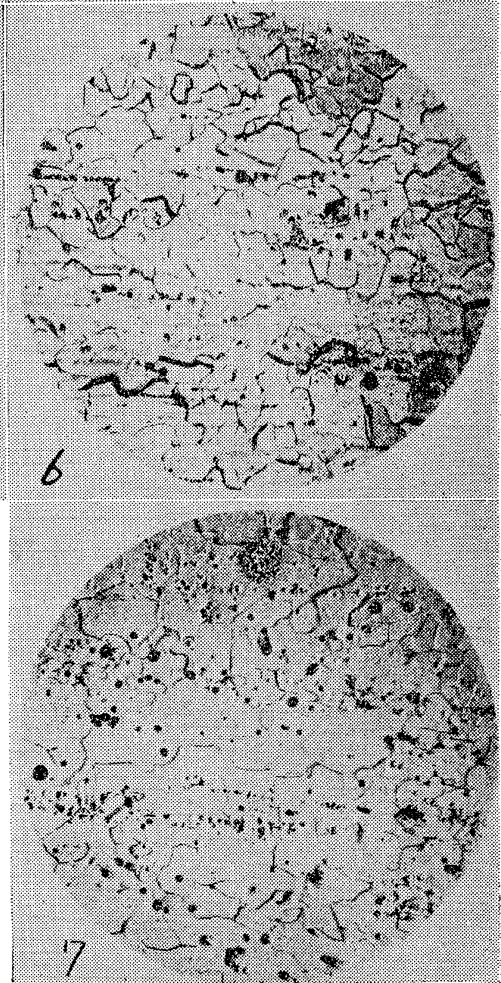

Photo. 2 Microstructure of High Purity Aluminums, Its Alloys and 99.7\% Aluminum (Annealed for $1 \mathrm{hr}$ at $\left.350^{\circ}\right)$ 
Fig. 9 Result of Erichsen Test of High Purity Al and its alloy sheet

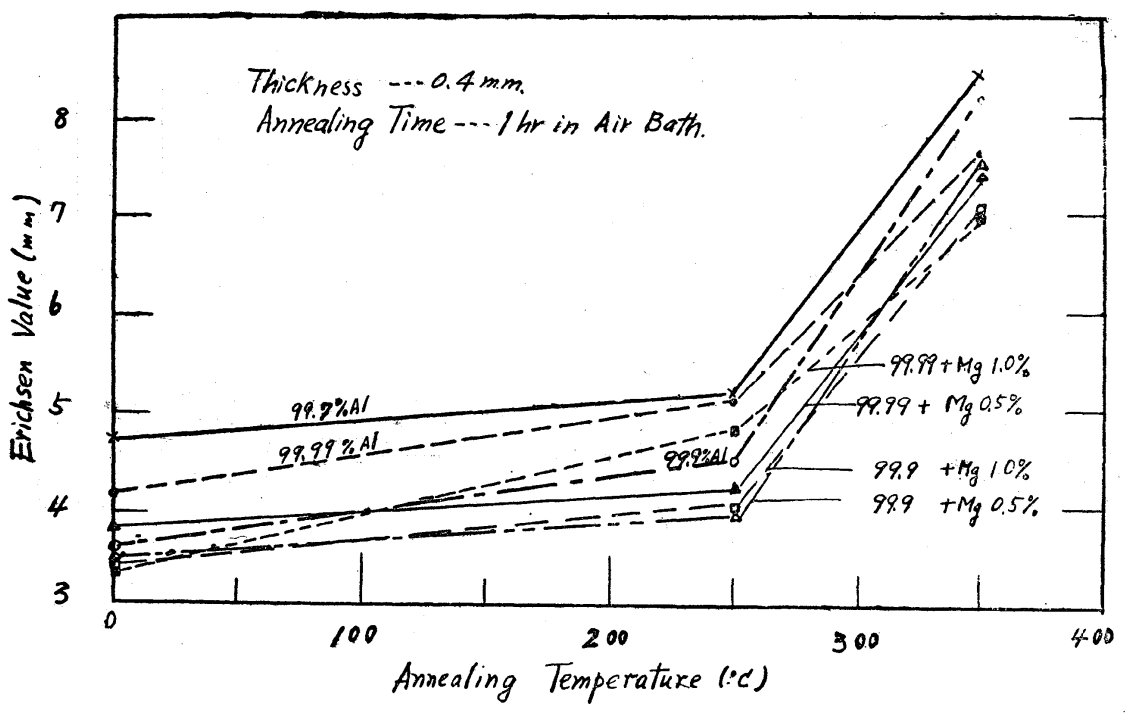

它ないが、軟質材を用い るとしても Mg 0.5\%な らばこの実験からはアル マイト処理でも58\%以上 の反射率は保証出来るわ けである。

次に99.9\% Al では電 解研磨て硬質材の反射率 は97\%を示し $\mathrm{Mg}$ の添加 量と共に低下する。軟質 材も之より幾分か低いが $\mathrm{Mg}$ 1.0\%のものでは硬 質材も略及同程度にな る。

之等をアルマイト処理 すれば何れも之より低下 することは前と同様であ Fig. 10 Intluence of My on the Reflectivity of the High Purity Aluminiums.

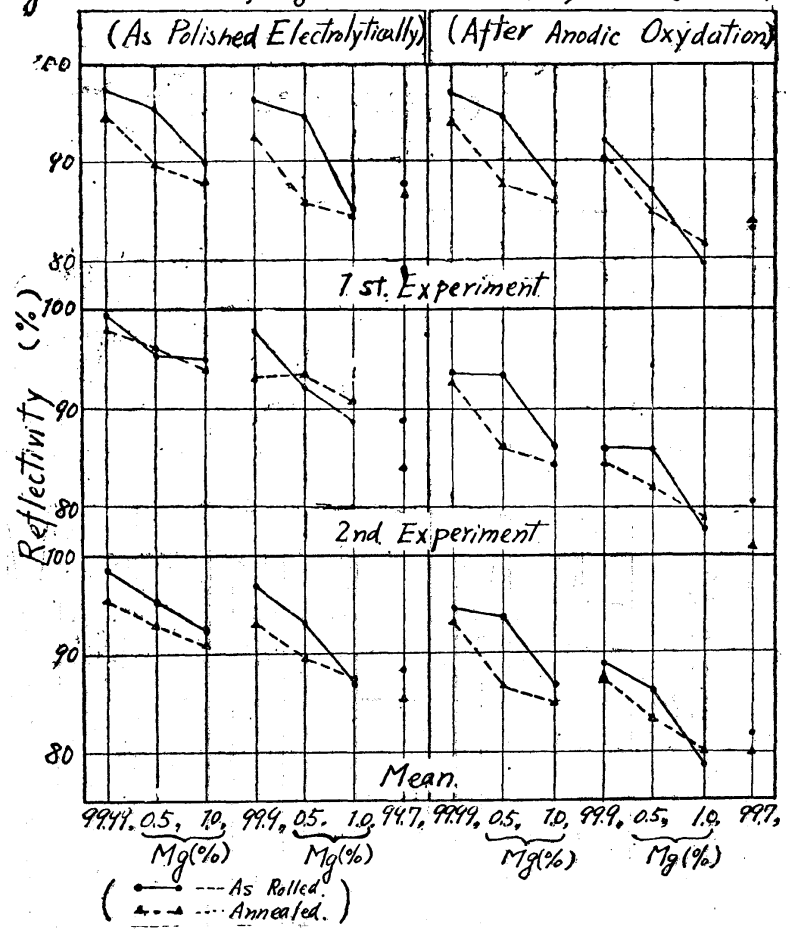

るが、99.9\% $\mathrm{Al} へ \mathrm{Mg}$ 涯加の場 合よりもその低下は秎々大きい。

結局アルマイト処理後に於ては硬 質材では $99.9 \% \mathrm{Al} に 0.5 \% \mathrm{Mg}$ を涯加したものは 99.9\% Al に何 も添加しないものより幾分反射率は 高く、軟化材では両者は略同值と見 てょい。

佮現在 $99.7 \% \mathrm{AI}$ 板が反射鏡にも 使用されているので $99.99 \%, 99.9$, 99.7\% Al の反射率の比較をして及 た結果を Fig.11に示した。即方軟 質材のアルマイト処理䒺のものでは 夫々 $93 \%$ 、88\%、80\%であつた。

\section{5）耐食性}

Fig. 12, Fig. 13 に試験結果を示 す。

即亏 $\mathrm{HCl}$ に対する耐蝕性（20\% $\left.\mathrm{HCl}, 22^{\circ} \times 3 \mathrm{hrs}\right)$ は99.99\% Al は $\mathrm{O}, \mathrm{x} / 2 \mathrm{H}, \mathrm{H}$ 材何れも $\mathrm{Mg}$ の添加と共 に僅かに劣化する程度である。99.9 \% $\mathrm{Al}$ では $\mathrm{Mg}$ の添加量と共に耐

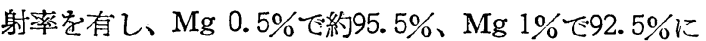
低下する。完全軟化 $\left(350^{\circ} \times 1 \mathrm{hr}\right)$ したものについて夫ょ 95.5\%、93\%、91\%と略及硬質材と平行的に低下してい る。

之を前記の様な条件でアルマイト処理をすると反射率 は何れる数\%低下するが、硬質材では $\mathrm{Mg}$ 0.5\%添加の ものは余り下らない様である。(93.5\%)

従つて Mg源加により全然反射率の低下がないとは云
蝕性は黛下する傾向にある。 $\mathrm{Al} \& 99.9 \% \mathrm{Al} \& \mathrm{Mg}$ 添加により向上し、何れ8 $0.5 \%$ 添加のもの最もよい。

今 $99.99 \% \mathrm{Al}+0.5 \% \mathrm{Mg}$ は $99.9 \% \mathrm{Al}$ に比輘して タると $\mathrm{HCl}$ に対しても $\mathrm{NaOH}$ に対しても为なり耐飭 性は優秀厄゙ある。
$\mathrm{NaOH}$ に刘する酎蝕性は全体の傾向として 99.99\% 
Fig. 11 Relation between Reflectivity and Purity of Aluminum

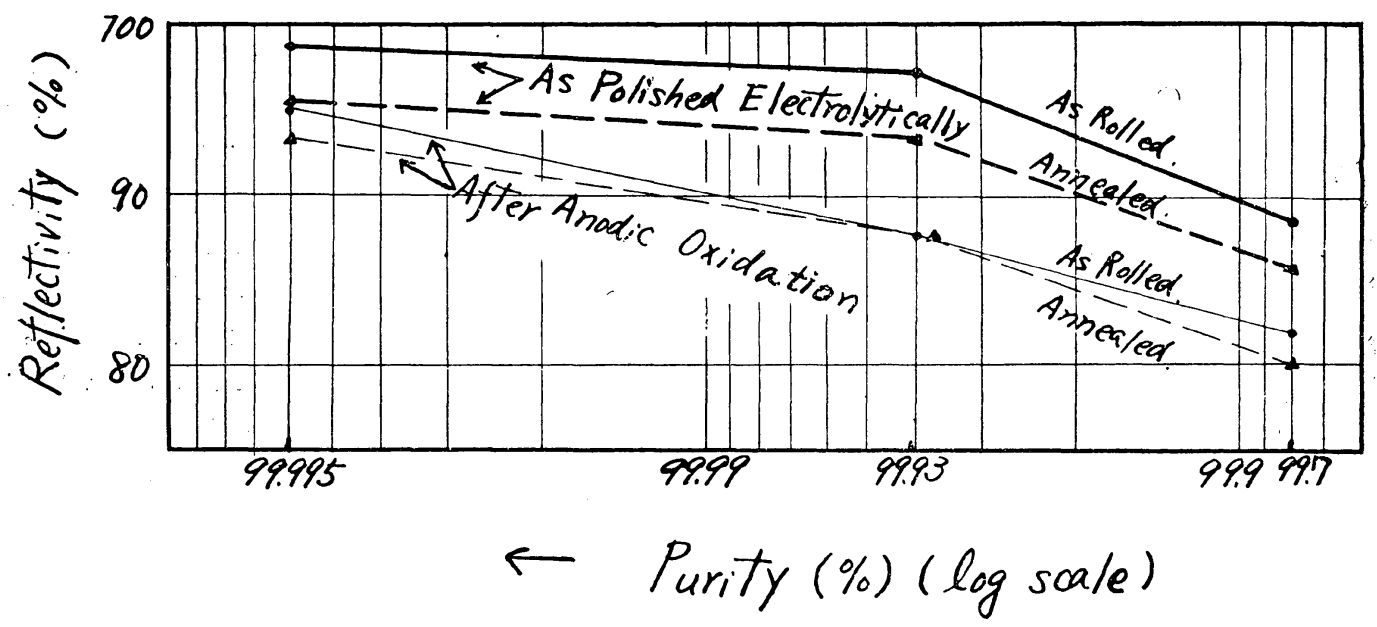

Fig 12 Result of Corrosion Test by HCl. ( $20 \% \mathrm{HCl}, 22 \times 3 \mathrm{nms})$

Fig. 13 Result of Corrosion Test by $\mathrm{NaOH}$ $\left(3 \% \mathrm{NaOH}, 22^{\circ} \times 3 \mathrm{hrs}\right)$

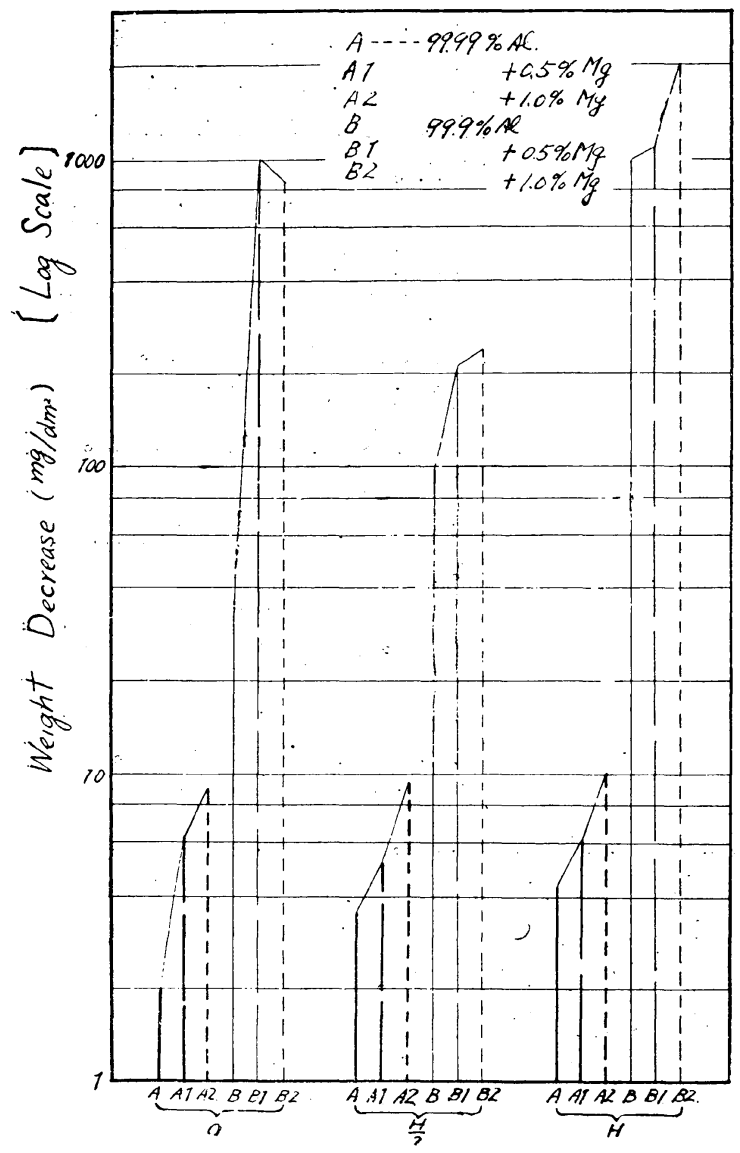




\section{結 論}

以上の結果を綜合して実用的見地から結論すると、次 の様なととが云える。

1）軟資材のアルマイト処理後のもの十区射率は 99.99 $\% \mathrm{Al}, 99.99 \% \mathrm{Al}+0.5 \% \mathrm{Mg}, 99.99 \% \mathrm{Al}+1.0 \%$ $\mathrm{Mg}, 99.9 \% \mathrm{Al}$ で夫々 93,87,85,87\%の值を示してい る。

2）軟質材 $99.99 \% \mathrm{Al}+0.5 \% \mathrm{Mg}$ は 99.9\% $\mathrm{Al}$ に比 較して、抗張力、硬度の点では同じ程度であるが、伸 エリクゼン值では稍々低い。従つて絞り加工性は幾分 特ちると思われるが、99.9\% Al より強度の大なるる のが得られる。即ち $99.99 \% \mathrm{Al}+0.5 \% \mathrm{Mg}, 99.9 \%$ Al では夫љ $9 \mathrm{~kg} / \mathrm{mm}^{2}, 7.5 \mathrm{~kg} / \mathrm{mm}^{2}$ である。命 99. $99 \% \mathrm{Al}+1.0 \% \mathrm{Mg}$ は $12 \mathrm{~kg} / \mathrm{mm}^{2}$, 即ち $3 \mathrm{~S}$ 程度の 強度をるつている。

3）而蝕性については軟資 99.99\% $\mathrm{Al}+0.5 \%$ は $\mathrm{Mg}$ 99. 9\% $\mathrm{Al}$ に比較して $\mathrm{HCl}$ 耐刢性も $\mathrm{NaOH}$ 耐創性 も相当優秀である。

要するに 99.99\% Al その儘では絞り加工性も悪く、 強度も弱いがこれに Mg を涯加した Reflectal Alloyな らば強さも $2 \mathrm{~S}, 3 \mathrm{~S}$ 程度となり加工も容易で従つて強度、 耐蝕性を上り褧求される場合は $99.9 \% \mathrm{Al}$ 上りもこの方 が推桨される。

それ故サーチライト、航空機の差陸燈、鉣山燈、汽関 車、自動車のーツドライト等の反射鏡として最適であ る。ヌブローチ、灰血、ライター、口紅容器、ボタン、 バツチ、宝石等の実用品装身具としての用途も今後益々 広まるものと信ずる。

(1) Schenk; Werkstoff Aluminium und scine anodische Oxidation, 699 714.

(2) Hase; Aluminium, 24 (1942) 140 141.

(3) R. Schnell ; Leicht metal Inform-Dienst, No.2, $\mathrm{I} / 2$ (1949) $11 \sim 16$.

(4) S. M. Lawrence; Sheet Metal Industries, 28, No. 286, Feb (1951) 141 145.

(5) R. G. Weigel ; Aluminium, 27, No. 1, Sept. (1951) $17 \sim 20$.

(6) J. Herenguel ; Metallurgia Italiana, 43, Feb. (1951) 72 73.

（7）中山：「俥金属」No. 1,61.

(8) W. Helling \& H. Neunzig; Metall (G), Oct. (1951) 424.

(8) .Modern Metals, spril (1953) 90.

(10) American Metal Market, 60, No. 83, May 1st (1953).

（11）国本：「軽金属」No.1(1951)47, No.2(1952)127)

（12）川島, 中村, 日本金属学会誌 B-16-1 (1952) 26.
（追 記）

(Photo. 1)

$$
\begin{aligned}
& 1 \cdots \cdots .99 .99 \% \mathrm{Al} \\
& 3 \cdots \cdots . / 1 \%+1 \% \mathrm{Mg} \\
& 5 \cdots \cdots . / 1+0.5 \% \mathrm{Mg} \\
& 7 \cdots \cdots .99 .7 \% \mathrm{Al}
\end{aligned}
$$$$
2 \cdots \cdots .99 .99+0.5 \% \mathrm{Mg}
$$$$
4 \text {......99. } 9 \% \mathrm{Al}
$$$$
6 \ldots \ldots . \|+1 \% \mathrm{Mg}
$$

(Photo. 2)

$$
\begin{aligned}
& 1 \cdots . . .99 .99 \% \mathrm{Al}(\phi 0.138 \mathrm{~m} / \mathrm{m}) \\
& 2 \cdots \cdots . \|+0.5 \% \mathrm{Al}(\phi 0.049) \\
& 3 . \cdots . . \prime \prime+1 \% \mathrm{Al}(\phi 0.046) \\
& 4 \cdots . . .99 .9 \% \mathrm{Al}(\phi 0.053) \\
& 5 \ldots . . . \prime \prime+0.5 \% \mathrm{Al}(\phi 0.046) \\
& 6 \ldots . . .11+1 \% \mathrm{Al}(\phi 0.038) \\
& \text { 7…...99.7\% Al ( } \phi 0.043) \\
& \text { ( ) …...Grain Size }
\end{aligned}
$$

(P56より)

\section{参 考 文 献}

1) 由島 栄; 電気化学 12,221 (1944)

2）室町 繁雄; 日本金属学会講演概要 (1951-10)

3) P.A. Jacquet; Compt rend 204, 1232 (1937) Metallurgist (Suppt to Enginner) April 29. P116 (I938)

4) 田島 栄; 電気化学14，129(1946) 日特許171, 886 金属17No. 4 (1947)

5) 伊 沢 呂; 日本金属学会請演概要 (1950-10) 日特許11069.

6）田島 栄; 中央航空研究研究所速報 (1944)

7) Hedges ; 金属及び合金の防蝕、Alの陽極処理 (1936)

8）呂金属誌 21 (1951)

9) Al.Desy and H.Haemers, Stakle and Eisen 61. 185 (1941)

10) H. Pary ; I. Igelsud and G.L Simard

11）田島 栄; 電気化学 14-32 (1945) 金属誌 $17-26$ (1947) 電気化学 15-17 (1947) 金属 17-26 (1947)

$$
\text { " "21-1 (1951) }
$$

12）木村、福島；都立工業将励館化学:开究報告 No. 13 (1950)

13）川崎、大形; 電気化学: 19-2 (1951)

14）早 坂; 日本特袘 3863 (1951)

15）伊沢 吕; 日本特站公報 (1951) 